\title{
Syphilis in Pregnancy: the Role of Nurses from the Family Health Strategy

\begin{abstract}
Juliana Alexandra Parente Sá Barreto1, Mirna Neyara Alexandre de Sá Barreto Marinho1,2, Eglídia Carla Figueiredo Vidal1,2,3,6, Emery Ciana Figueiredo Vidal1,3,4, Ana Maria Machado Borges 1,2,5, Antônio Germane Alves Pinto1,3, Priscila de Souza Aquino ${ }^{6}$, Fernando Luiz Affonso Fonseca7,8
\end{abstract}

\section{Abstract}

This is a descriptive-exploratory study of a qualitative nature, which aimed to know the steps taken by the Family Health Strategy nurses concerning cases of syphilis during pregnancy. A total of 16 nurses who work in Barbalha, a municipality in the state of Ceará, Brazil, provided the necessary data by means of a semi-structured interview. Data organization was performed using the Collective Subject Discourse (CSD), and the analysis of results was conducted based on the available literature on the theme. From what could be observed, only one the participants had followed up a syphilis case during pregnancy. They, however, mentioned the performance of educational activities, the major actions to be taken after the diagnosis, and the difficulties they might come across during the treatment. The conclusion was that due to data scarcity in the literature, further studies on this theme should be conducted so that health care management can be improved.

\section{Introduction}

Syphilis is an infectious disease of chronic evolution, caused by the bacterium Treponema palladium, which practically affects all organs and systems of the body. It is mainly sexually transmitted, but it may also be spread through transfusion of contaminated blood, or transplacentally causing congenital syphilis [1].

Despite its ancient origin, syphilis is still considered a major health issue that imposes a great challenge to health services. The World Health Organization (WHO) reveals that approximately 12 million new cases arise annually among the adult population worldwide. In Brazil,
1 Membro do Grupo de Pesquisa Clínica, Cuidado e Gestão em Saúde, GPCLIN. Universidade Regional do Cariri, URCA Crato, Ceará, Brasil.

2 Hemocentro Regional de Crato, HEMOCE. Crato, Ceará, Brasil.

3 Departamento de Enfermagem da Universidade Regional do Cariri, URCA Crato, Ceará, Brasil.

4 Faculdade de Medicina do ABC, FMABC. Santo André, São Paulo, Brasil.

5 Faculdade Leão Sampaio. Juazeiro do Norte, Ceará, Brasil.

6 Universidade Federal do Ceará, UFC. Fortaleza, Ceará, Brasil.

7 Departamento de Ciências Biológicas, Universidade Federal de São Paulo, UNIFESP, Diadema, SP, Brasil.

8 Laboratório de Análises Clínicas, Faculdade de Medicina do ABC, Santo André, SP, Brasil.

\section{Contact information:}

\section{Fernando Luiz Affonso Fonseca.}

”profferfonseca@gmail.com
Keywords
Syphilis; Pregnancy; Pregnancy
Complications, Infectious;
Health Units; Public Health 
the average prevalence of the disease in parturients ranges from $1.4-2.8 \%$, with a vertical transmission rate of around $25 \%$ [2].

The increase in congenital syphilis cases, along with the severe consequences caused by the disease, highlights the flaws in prenatal care in relation to the control of the infection, especially because the clinical protocol is widely known, with a blood serum screening test for syphilis and a low-cost treatment [3].

The Ministry of Health in Brazil recommends the performance of a non-treponemal test during the first prenatal visit, especially during the first quarter of pregnancy, and a second test close to the $30^{\text {th }}$ week of pregnancy [4].

Since 1986, notifications of syphilis in pregnancy and congenital syphilis have become mandatory owing to the alarming rates of prevalence, and they are recorded in the Information System for Notifiable Diseases (SINAN). In the year 2004, a multicentric study carried out in six Brazilian capital cities showed that syphilis in pregnancy had a prevalence rate of $1.9 \%$, and this rate increased to $3.6 \%$ among women with sexually transmitted infections (STIS) [4].

In a study performed in 2004, a 1.6\% prevalence of the infection in pregnant women was estimated, representing approximately 50,000 parturients with active syphilis. The same study also estimated that there were around 15,000 children being born with congenital syphilis, a disease that has one of the highest transmission rates during the pregnancychildbirth cycle [5].

Regarding related issues, congenital syphilis may cause not only lesions in many bones and extremities (usually with symmetric distribution), but also hepatosplenomegaly, low birth weight, pneumonia, hyperbilirubinemia, limbs paralysis and Central Nervous System (CNS) abnormalities [6].

The incidence and sequelae of congenital syphilis are directly related to the quality of prenatal care; therefore, based on this fact, the Ministry of
Health has been taking actions to eradicate congenital syphilis from the country, like the "Projeto Nascer Maternidades", implemented in 2002 by the Sistema Único de Saúde (Unified Health System), better known by the acronym SUS [7]. The project guidelines establish that the Venereal Disease Research Laboratory test (VDRL) should be performed in all parturients that do not confirm the negative serological results for syphilis, and that prophylactic and/or therapeutic measures should be taken in the event of a positive outcome.

Health professionals who work at Primary Healthcare Units, nurses included, play an important role in this context due to their interaction and follow up with the parturient during prenatal care period.

Health promotion actions that aim to ensure the integrity of primary healthcare are of utmost importance. Therefore, all professionals involved in this process can be aware of all the steps that involve detection, diagnosis and treatment of syphilis, which will support their actions and strategies [8].

A study with professionals that are in charge of prenatal visits at SUS in Rio de Janeiro aimed to analyze their knowledge, attitudes and practices in relation to the management of syphilis during pregnancy. Results showed that a great number of the professionals had participated in some sort of training on the theme, and that they had the right knowledge about syphilis transmission; however, many of them did not know about the epidemiological situation of congenital syphilis in the country or even in the municipality where they work. Moreover, the study also revealed the difficulties these professionals face to introduce the topic to the patients and their partners [8].

Taking into consideration the aspects here exposed, the interest to perform the current study came to the author when, during her graduation internship, she had to assist a pregnant patient with syphilis. 
According to this perspective, the aim of this study is to identify the actions of nurses from the Family Health Strategy in regard to syphilis during pregnancy.

\section{Method}

This is a descriptive-exploratory study of a qualitative nature. The study took place at Family Primary Healthcare Units in Barbalha, a municipality in the state of Ceará, Brazil. Barbalha has a total of 23 of these centers located in urban and rural areas. Data collection occurred over the months of June and July, 2012.

The study population was pooled from Family Health Strategy (FHS) healthcare professionals, totaling 23 nurses from the above mentioned municipality. The following inclusion criteria was adopted for recruitment: nurses who were working in the area over a period of six months or longer due to the closer proximity to the scenario and the probable greater knowledge on the subject; those who were at the units when data were collected and who accepted to participate. Among the 23 nurses, 16 were included in the study and 07 did not comply with the established parameters of inclusion: 01 was on maternity leave, 04 were on vacation, and 02 did not meet the 6-month experience criterion.

The technique employed for data collection was a semi-structured interview, which included questions on the participation of nurses in the FHS program in regard to syphilis during pregnancy.

In order to register all the information supplied, all the answers were recorded and then transcribed for further analysis.

The organization and the descriptive analysis of the data were made through the Collective Subject Discourse (CSD), which consists of the organization and tabulation of qualitative data of oral nature obtained from statements, newspaper and weekly magazine articles or papers. The central ideas are extracted as well as the anchors and their corres- ponding key expressions [9]. The analysis of the results was based on the available literature on the theme.

The study followed the guidelines established in Resolution no. 196/96 [10], which regulated trials involving human subjects at the time this study was conducted. The study was approved by the Research Ethics Committee from the Universidade Regional do Cariri (URCA), in Crato (CE, Brazil) under the number 60/2010.

\section{Results and Discussion}

Nine out of the sixteen interviewed nurses were females, and the ages of all professionals ranged from 22 to 44 years. Twelve nurses had graduated from college at least two years prior to the beginning of the current study, and only two professionals had completed their studies in a period less than two years. As to specializations, Collective Health was the most often mentioned area. Concerning experience in family health strategy, eleven nurses had two or more years of practice.

By means of the recorded answers from the participants, three central ideas came up and organized by the CSD.

\section{Central Idea 1. Interventions performed by the nurse after the pregnant patient is diagnosed with syphilis}

I've never had a case of syphilis in pregnant patients. If I did, I would enter the information into the patient's medical record, give her orientation on the disease, order VDRL testing for this patient's partner and children, and refer her to a high-risk prenatal doctor. Then both the doctor and I would simultaneously follow up the patient. In case the partner did not have the disease, I would see that he would not get infected. I would also notify the Municipality Department of Health through SINAN.

CSD A. 
In the unit I work at there was once a case of syphilis in pregnancy. The doctor from the Primary Healthcare Unit referred the patient to the high-risk prenatal care center, repeated the test and prescribed the medication. She had 3 monthly prenatal visits, one with me, one with the FHS doctor, and the other with a high-risk prenatal doctor.

CSD B.

\section{Central Idea 2. Difficulties nurses usually find in relation to syphilis in pregnancy}

Maybe the difficulties are associated with the low adherence to the treatment from the patient's and her partner's parts, the obstacles to the access to the high-risk prenatal care center, the lack of interaction between nurses and doctors from PHU, the lack of a protocol that supports nursing assistance to pregnant women with syphilis.

CSD A.

I had no difficulties in relation to the only case of syphilis in pregnancy I had. Both the patient and her partner adhered to the treatment, and the patient was followed up by me, a doctor from the PHU, and a high-risk prenatal doctor. As a result, the baby was not born with congenital syphilis.

\section{CSD B.}

\section{Central Idea 3. Educational strategies performed by nurses regarding syphilis during pregnancy}

When it comes to educational strategies, I deliver lectures on health education, instruct patients during their visits, work together with educational institutions, have a differentiated approach with adolescents, gather patients in rounds of conversation, make use of information booklets, and seek for other professionals' advice.

CSD A.
Central idea 1 shows a reduced number of syphilis cases in pregnancy in the studied scenario, a reality that was also revealed in a study conducted at Dr. Miguel Riet Corrêa Jr. University Hospital, from the Universidade Federal do Rio Grande, in the state of Rio Grande do Sul. Among the 611 pregnant patients who had their regular prenatal checkups, 567 were serologically tested for syphilis and only 3 tested positive [11].

Concerning the interventions performed by nurses after the first diagnosis of a pregnant patient with syphilis, they reported that they would refer her to a doctor and order VDRL testing for the patient's partner.

Therefore, despite the inadequate protocol for medical assistance, the pregnant patient does not miss the opportunity to be treated. Moreover, it is known that in municipalities where prenatal checkups are not performed by doctors, it is the nurse that refers the patient straight to the specialized service.

As to the performance of VDRL tests in the partner, the involvement of the professional in charge of the patient's follow-up is of utmost importance since reinfection may occur once he tests positive for the disease.

A study with 102 professionals from primary healthcare revealed that nearly half of the participants did not have an adequate conduct regarding patients' partners. In such cases, it was the pregnant patient who informed her companion about the need for VDRL testing and gave him orientation on the treatment [12]. Therefore, the screening and control of partners, so that they can undergo the treatment in the event of the disease and do not suffer from its consequences, are steps of significant relevance [13].

Notification of such cases to SINAN is mandatory and highly recommended for the follow up of patients by the Ministry of Health. Interestingly, a study shows that only $8.2 \%$ of nurses state that syphilis during pregnancy and congenital syphilis are not diseases of mandatory notification [12]. 
VDRL testing is recommended to the other children from infected mothers, a practice of extreme importance since $50 \%$ of newborns from untreated or improperly treated VDRL positive mothers do not manifest the symptoms of syphilis [14].

In relation to the steps to be followed once the patient tests positive, the health professionals reported that information on the disease is provided to all patients, an action that helps in the fight against syphilis reinfection during pregnancy and congenital syphilis. In this scenario, patients can also supply this information to their community.

On the other hand, a study involving 46 pregnant women with syphilis revealed an absence of actions when it came to counseling on the disease and the importance of the use of condoms, indicating that the quality and effectiveness of prenatal care for the reduction of the vertical transmission was low since 16 newborns were diagnosed with congenital syphilis [15].

It was quite clear in the reports that nurse professionals simultaneously followed up patients in a high-risk prenatal condition, and that counterreferral is of extreme importance along with multidisciplinary assistance. Under this perspective, the expertise of each category of professionals, doctors and nurses, is unique and irreplaceable. In compliance with the Ministry of Health, prenatal care must be provided by a multiprofessional health care team [18]; therefore, such professionals should team up, and not only guide but also support patients in their complaints, doubts and decisions.

Central idea 2, which came up from the difficulties found by the participants in the current study, highlights the fact that the reluctance of partners to adhere to therapy has proven a hindrance to the treatment of syphilitic pregnant patients. In a study performed with 1500 parturients, it was observed that among those who tested positive for VDRL, only $50 \%$ convinced the partner to participate in prenatal care and be guided on the treatment of syphilis; an even smaller rate of patients managed to have the partner tested, but not all of them agreed to be treated [13].

Another study on the epidemiology of syphilis in pregnancy showed that only $24.1 \%$ of the patients reported that their partners had been treated, $65.5 \%$ informed that their partners were not treated and $10.3 \%$ were not able to provide the information [16]. Among the 14 treated cases, only 6 completed the treatment, representing $10.3 \%$ of the total sample.

Another barrier professionals have to overcome in the treatment of pregnant patients with syphilis is the difficulty found in making the patient herself adhere to the therapy. A study revealed the following results: $63.6 \%$ of the pregnant patients with syphilis properly completed the treatment program; $9.1 \%$ did not undergo any kind of treatment; $27.3 \%$ inadequately went through the treatment program, an alarming situation since the cure directly depends on proper care [17]. Still within this context, syphilis vertical transmission rate ranges from $30 \%$ to $100 \%$, depending on the stage of the disease and the fetus exposition to the bacterium [18], thus confirming the high transmission rate of the infection.

The lack of interaction between nurses and doctors from the PHU, with a resultant harm to the treatment of syphilitic pregnant patients, also came up in the statements. Nurses should understand the peculiarities of each pregnant patient and team up with other professionals to develop actions that provide interdisciplinary assistance.

The unavailability of a protocol for nursing conduct in the event of syphilis during pregnancy in the municipality was also mentioned as one of the difficulties. In such case, the standardization of procedures and the guarantee of a better assistance become compromised. Nursing practice concerning the administration of medications in public health and the request for complementary exams are endorsed by law enforcement (Act No. 7498/1986 [19] and Decree No. 94406/1987 
[20]) concerning professional practice in nursing. Ordinance No. 2488/2011 [21] establishes that in primary healthcare it is the nurse's role to carry out nursing appointments, procedures and group activities as well as order complementary exams, prescribe medications and, whenever needed, refer the patient to other services. Therefore, the non-compliance of the legal provision not only hinders a nurse's autonomy but also assistance to the general population. Nevertheless, the Ministry of Health recommends that the nurse should not conduct high-risk prenatal follow-ups alone [14].

Central idea 3 shows that nurses try to perform their educational activities through traditional strategies. Therefore, the incorporation of new educational technologies, which go beyond health educational activities based on targeted actions are made necessary. The idea also reveals that nurses cannot identify the needs and expectations of the participants involved in the process [22].

The statements also suggested partnerships with schools so that the theme can be exposed. School environment is unique for the acquisition of knowledge and skills, and the aim would be an attempt to establish a change in habits of children and adolescents [22].

The support supplied by other professionals in educational strategies was also mentioned, showing that the combined efforts of the health professionals involved are important for the success of the actions with pregnant women. Thus, such patients may coach family members by supplying them with preventive information and play an important role in the acquisition and maintenance of positive habits in the family [23].

\section{Final Considerations}

Regarding the subject here studied, it can be observed that the information supplied by the professionals reflect the reality of their practices. The findings allow for some considerations on the role of the nurse in the specific process of following up the pregnant woman.

By mentioning that they never followed up cases of syphilis during pregnancy in the units where they work, these professionals corroborate some hypotheses, like for example the high effectiveness of the health educational strategies regarding the fight against STIs and/or the poor quality of laboratory test analyses with false negative results.

Through statements given by the professionals it could be observed that despite their little experience with pregnant patients with syphilis, they mentioned the main steps to be taken after the diagnosis: enter the information into the patient's medical record; give orientation on the disease, which includes the risk of congenital syphilis; explain the consequences of syphilis and how to prevent transmission to their partners; ask partners and children to undergo a VDRL test; refer the patient to a doctor from the unit in the high-risk prenatal care unit and simultaneously follow her up; notify the Municipality Department of Health through SINAN.

Regarding the difficulties found during the treatment, it was revealed that these were detected among patients and their partners, health professionals and even in the health system itself. Low adherence to the treatment in patients and their partners, the lack of interaction between nurses and doctors from the PHU and the lack of a protocol that supports nursing assistance to pregnant women with syphilis were hindering factors mentioned by the interviewees.

However, it is important to point out that one of the study participants reported no difficulties in the treatment of a pregnant patient diagnosed with syphilis owing to the fact she and her partner adhered to the therapy and the woman was monthly followed up by the nurse, the PHU doctor and a high-risk prenatal doctor. Interestingly, this was the only study participant who assisted a pregnant patient with syphilis in the FHS unit where the professional worked. 
When it came to the educational strategies applied, participants mentioned giving lectures, instructing patients during their visits, establishing partnerships with educational institutions, approaching adolescents distinguishably, gathering patients in rounds of conversation, making use of information booklets and seeking for other professionals' advice. The statements showed the important role the nurse plays in regard to sparking the patient's attention to the pathology by showing her the consequences implied once the treatment is not carried out and the co-responsibility for the actions taken.

The lack of a protocol that supports nursing assistance to pregnant women with syphilis limits the professional's activities; moreover, the absence of interaction with doctors from the PHU and the poor interactivity among professionals compromise the interdisciplinarity of concepts and practices.

Differently from what was here proposed, the studies on which this research was based referred to quantitative approaches only due to the scarcity of literature on the theme; therefore, the quality of the analysis was partially compromised.

Last but not least, it was also the aim of this study to stimulate nursing students and nurses to think over the importance of these strategies and the possible ways to improve post-diagnostic actions as well as to try to find solutions for the difficulties here exposed by means of the performance of other studies on the theme.

\section{References}

1. Cavalcante AES, Silva MAM, Rodrigues ARM, Netto JJM, Moreira ACA, Goyanna NF. Diagnóstico e tratamento da sífilis: uma investigação com mulheres assistidas na atenção básica em Sobral, Ceará. DST - J bras Doenças Sex Transm. 2012; 24(4): 239-45.

2. Magalhães DMS; Kawaguchi IAL; Dias A; Calderon IMP. Sífilis materna e congênita: ainda um desafio. Cad. Saúde Pública, Rio de Janeiro, 29(6): 1109-1120, jun, 2013

3. Amaral E. Sífilis na gravidez e óbito fetal: de volta para o futuro. Rev Bras Ginecol Obstet. 2012; 34(2): 52-5

4. Ministério da Saúde (BR). Manual de controle das doenças sexualmente transmissíveis. $4^{\mathrm{a}}$. ed. Brasília: Ministério da Saúde; 2006.

5. Ministério da Saúde (BR). Coordenação de Doenças Sexualmente Transmissíveis e Aids. Sífilis: Estratégias para Diagnóstico no Brasil. Brasília (DF): MS; 2010.

6. Silva SFM, Prebianchi PA, Dias CF, Akel Júnior NA, Dalvi LG, Frauches DO. Alterações ósseas em lactentes com sífilis congênita. DST - J bras Doenças Sex Transm. 2009: 21(4): 175-9.

7. Ministério da Saúde (BR). Secretaria de Políticas de Saúde. Coordenação Nacional de DST/HIVIAIDS, Áreas Técnicas de Saúde da Mulher e Nutrição. Manual para Oficina de Capacitação Projeto Nascer-Maternidades. Brasília: Ministério da Saúde; 2002.

8. Domingues RMSM, Lauria LM, Saraceni V, Leal MC. Manejo da sífilis na gestação: conhecimentos, práticas e atitudes dos profissionais pré-natalistas da rede SUS do município do Rio de Janeiro. Ciênc. saúde coletiva: 2013; 18(5): 1341-51.

9. Lefèvre $F$, Lefèvre AMC. Princípios básicos e conceitos fundamentais do discurso do sujeito coletivo. $2^{a}$ ed. Caxias do Sul: Educs; 2005. O discurso do sujeito coletivo: um novo enfoque em pesquisa qualitativa; desdobramentos. p. 15-35.

10. Ministério da Saúde (BR). Conselho Nacional de Saúde, Comissão Nacional de Ética em Pesquisa. Resolução Nº 196 de 10 de Outubro de 1996: aprova as diretrizes e normas regulamentadoras de pesquisas envolvendo seres humanos. Brasília: Ministério da Saúde; 1996.

11. Baumgarten VZ, Longhi K, Bianchi MS, Gonçalves CV. Perfil sorológico das gestantes atendidas no pré-natal de um hospital universitário no sul do Brasil. Vittalle: 2011; 23(1): 67-74.

12. Lima NBG, Araújo MAL, Silva DMA, Melo SP. Conhecimento dos enfermeiros acerca do manejo da gestante com exame de VDRL reagente. DST - J bras Doenças Sex Transm. 2011; 23(4): 188-93.

13. Oliveira DR, Figueiredo MSN. Abordagem conceitual sobre a sífilis na gestação e o tratamento de parceiros sexuais. Enferm em Foco. 2011; 2(2): 108-111. 
14. Ministério da Saúde (BR). Pré-natal e puerpério, atenção qualificada e humanizada: manual técnico. Brasília: Secretaria de Atenção à Saúde. Departamento de Ações Programáticas Estratégicas. Área Técnica de saúde da Mulher. Brasília: Ministério da Saúde; 2005.

15. Domingues RMSM, Saraceni V, Hartz ZMA, Leal MC. Sífilis congênita: evento sentinela da qualidade da assistência prénatal. Rev Saúde Pública. 2013; 47(1): 147-57

16. Campos AnaLuiza de Araujo; Araujo MariaAlix; leite; MeloSimone Paes de; Andrade Roumayne Fernandes Vieira; Gonçalves Marcelo Luiz Carvalho. Sífilis em parturientes: aspectos relacionados ao parceiro sexual. Rev. Bras. Ginecol. Obstet. [online]. 2012, vol. 34, n. 9 [citado 2014-01-14], pp. 397-4-2. Disponível em: http://www.scielo.br/scielo.php?script=sci arttext\&pid=S010072032012000900002\&lng=pt\&nrm=iso. ISSN 0100-7203. http://dx.doi.org/10.1590/S0100-72032012000900002.

17. Leitão EJL, Canedo MCM, Furiatti MF, Oliveira LRSO, Diener LC, Lobo MP et al. Sífilis gestacional como indicador da qualidade do pré- natal no Centro de Saúde n.2 Samambaia-DF. Com. Ciências Saúde. 2009; 20(4): 307-14.

18. Souza BC, Santana LS. As consequências da sífilis congênita no binômio materno-fetal: um estudo de revisão. ICSA. 2013; 1(3): 59-67.

19. Brasil. Lei n. 7.498, de 25 de junho de 1986. Dispõe sobre a regulamentação do exercício da Enfermagem e dá outras providências. Brasil: 1986

20. Brasil. Decreto n.94.406, de 08 de junho de 1987. Regulamenta a Lei 7.498/1986. Brasil: 1987.

21. Brasil. Portaria $n^{\circ} 2.488$, de 21 de outubro de 2011. Aprova a Política Nacional de Atenção Básica, estabelecendo a revisão de diretrizes e normas para a organização da Atenção Básica, para a Estratégia Saúde da Família (ESF) e o Programa de Agentes Comunitários de Saúde (PACS).

22. Gubert FA, Santos $A C L$, Aragão KA, Pereira DCR, Vieira NFC, Pinheiro PNC. Tecnologias educativas no contexto escolar: estratégias de educação em saúde em escola pública de Fortaleza - CE. Rev. Eletrônica Enferm. 2009; 11(1): 165-72.

23. Reis DM, Pitta DR, Ferreira HMB, Jesus MCP, Moraes MEL, Soares MG. Educação em saúde como estratégia de promoção de saúde bucal em gestantes. Ciênc. saúde coletiva. 2010; 15(1): 269-76.
Publish in International Archives of Medicine

International Archives of Medicine is an open access journal publishing articles encompassing all aspects of medical science and clinical practice. IAM is considered a megajournal with independent sections on all areas of medicine. IAM is a really international journal with authors and board members from all around the world. The journal is widely indexed and classified Q1 in category Medicine. 